\title{
The Classification of The Element and Principle in The Islamic Quality Management System: A Narrative Review Paper
}

Mohd Sadiq Mohd Mokhtar, Fadzila Azni Ahmad

To Link this Article: http://dx.doi.org/10.6007/IJARBSS/v11-i11/11582

DOI:10.6007/IJARBSS/v11-i11/11582

Received: 17 September 2021, Revised: 19 October 2021, Accepted: 01 November 2021

Published Online: 15 November 2021

In-Text Citation: (Mokhtar \& Ahmad, 2021)

To Cite this Article: Mokhtar, M. S. M., \& Ahmad, F. A. (2021). The Classification of The Element and Principle in The Islamic Quality Management System: A Narrative Review Paper. International Journal of Academic Research in Business and Social Sciences, 11(11), $882-893$.

Copyright: @ 2021 The Author(s)

Published by Human Resource Management Academic Research Society (www.hrmars.com)

This article is published under the Creative Commons Attribution (CC BY 4.0) license. Anyone may reproduce, distribute, translate and create derivative works of this article (for both commercial and non-commercial purposes), subject to full attribution to the original publication and authors. The full terms of this license may be seen at: http://creativecommons.org/licences/by/4.0/legalcode

Vol. 11, No. 11, 2021, Pg. $882-893$

Full Terms \& Conditions of access and use can be found at http://hrmars.com/index.php/pages/detail/publication-ethics 


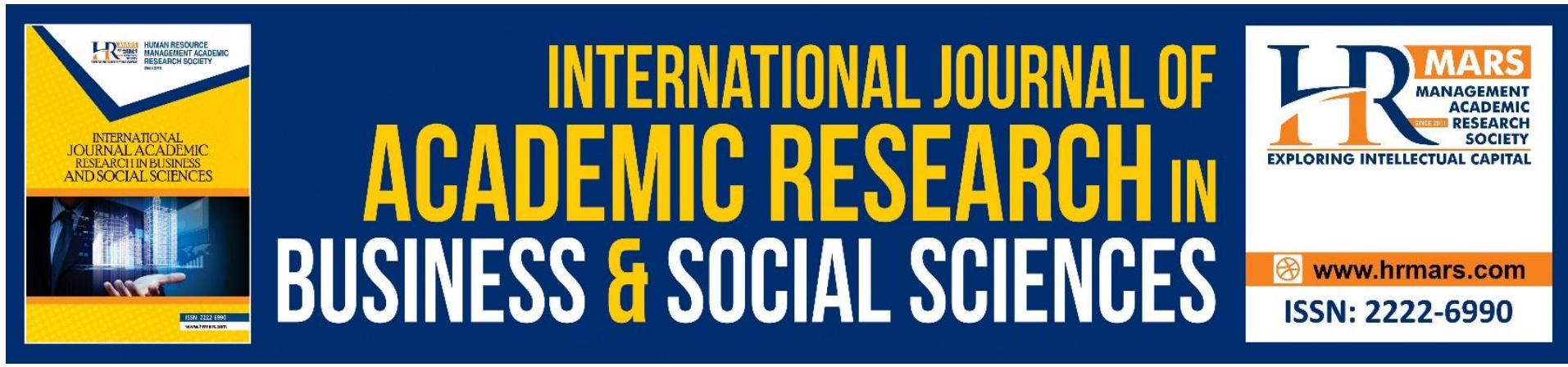

\title{
The Classification of The Element and Principle in The Islamic Quality Management System: A Narrative Review Paper
}

\author{
Mohd Sadiq Mohd Mokhtar \\ Centre for Islamic Development Management Studies (ISDEV), Universiti Sains Malaysia, \\ Penang, Malaysia \\ Email: sadiqmokhtar@gmail.com
}

\author{
Fadzila Azni Ahmad \\ Centre for Islamic Development Management Studies (ISDEV), Universiti Sains Malaysia, \\ Penang, Malaysia \\ Email: sukainah@usm.my
}

\begin{abstract}
Quality management concepts has shown to be a vital concept in the management of the institutions though out the world. Therefore, Islamic quality management concepts has also seen to be discussed among researchers and practitioner, specifically in the Muslim world. The aim of this study is to determine all Islamic quality management concepts that has been discussed and to classify these concepts into elements and principles based on what has been discussed. In order to achieve these aims, this study will be using qualitative narrative review method which will focuses on the literatures that are obtained from the systematic searching and also manual searching. This study found out that there are many concepts in Islam which are related to quality and several of these concepts has been classify by previous researchers into elements and principles. However, certain concepts have shown mixture of classifications and some concepts does not been classified and remain as concepts. Finally, this study will provide a much clearer classifications of these concepts which can be used for further study in the development of model or framework.
\end{abstract}

Keywords: Quality, Islamic Quality Management, Narrative Review.

\section{Introduction}

The management system has evolved and progressed throughout the years since the early introduction of management theory by Frederick Taylor which authored The Principles of Scientific Management in 1909. In the 1980s, a new phase of management began known as quality management system. The western organization started to study and look east towards Japan (Olejniczak, 2013) due to the nation successful in global competitions in offering product and services of superior quality with relatively low prices (Kamaluddin et al., 2014). Since World War 2 ended, western experts such as Edward Deming, Joseph Juran and 
James Abegglen started the journey to Japan to help the Japanese recover from the war and learn from the Japanese people (Kamaluddin et al., 2014; Olejniczak, 2013). The Japanese adapted the management system and modified the management system to fit the local context. The Japanese success has caught attention among other nation to learn this new quality management style which includes Islamic nation such as Malaysia.

In 2005, Malaysia introduces quality management from Islamic perspectives which is known as Quality Management from Islamic Perspectives (MS1900). The reason for this initiative is that to fill the gap existed within the conventional quality standards (ISO 9001) which are on internal or spiritual aspects. However, Basir et al (2017); Hasliza et al (2016); AlBanna et al (2015); Sarion et al (2014) similarly agreed that the basis of development of MS1900 was conventional quality management standards ISO 9001. Equally important, Mohamad \& Mansor (2018) argued that the only difference between MS1900 and ISO 9001 was MS1900 approach emphasizes on the importance on understanding shariah requirements. Therefore, even though MS1900 was initiated to fill the gap of the conventional quality standards, the basis of MS1900 was still from the conventional quality standards model.

This argument has been criticized by researcher Ahmad (2019) which mentioned that conventional or western quality management paradigm was unsuitable to be the basis of Islamic quality management due to the characteristic of conventional quality management was too attach to materialistic and tangible aims of commercialization, business strategy, profit maximization and customer satisfaction. While Islamic quality management paradigm must be holistic and compromise all aspects within the Islamic philosophy (Ahmad, 2019). This was proven by Othman (2017) which stated that the concept of customer satisfaction within the quality management should be referred to the concept of maslahah ummah. Other than the concepts of customer satisfaction which are differ from the Islamic philosophy, Ahmad (2019) argued that the concepts of Total Quality Management which are the major concepts conventional quality management is totally different from the concept within the Al Quran such as Hasanat, Toyyibat, al Khair, Itqan and al 'Maruf.

Therefore, with the existence of concepts related to Islamic quality management system which from Quran and Islamic philosophy which has been mentioned by Ahmad (2019) and Othman (2017), this study wanted to conduct a narrative review on past researchers literature which has mentioned on the concepts related to Islamic Quality Management System. This concepts which has been found will then be categorized into elements and principles which are the basic aspect in construct a model. The reason for this categorization was to assist further study on Islamic Quality Management System which is to construct a model or framework which will require to identify the elements and principles of Islamic Quality Management System. This is in line with findings from Azrin, Amirul and Hakim (2015) which mentioned that there is need to construct a Islamic management model which are based on Islamic philosophy and Islamic context. Therefore, the result of this paper will eventually assist the construction of Islamic Quality Management System model. However, the objective of this research paper was only to determine all concepts which has been mentioned by previous researcher and categorized it into elements and principles. 


\section{Research Method}

This paper adopts the narrative reviews method in explaining the research questions pertaining to the Islamic Quality Management System. The narrative reviews fall under the category of qualitative meta-analysis alongside the systematic review. The concepts of the narrative reviews involve the explanation of the research questions that focuses on the texts and language in interpreting the storyline (Ferrari, 2015).

This paper aims to:

1. To identify the concepts related to Islamic Quality Management System based on past research

2. To identify the classification made by past researchers on these concepts into elements and principles

The two methods were used in determining the relevant articles, which are through internet-based search and manual search. First, two internet-based databases (Scopus and Google Scholars) were used as the main search engine. This is because the papers related to Islamic Quality Management System are restricted to be published in the top-referred journals. Second, further articles were identified through a manual search of reference lists from retrieved papers. Some of the papers which could not be obtained its full paper by using internet method then will be identified through manual search. The databases were used again to retrieve the abstract and if appropriate, the full-texts articles.

In the narrative review, the inclusion and exclusion for the studies must be drawn accordingly. The paper utilises the narrative reviews by including (1) the studies were written in English and Bahasa Melayu; (2) were published in full; (3) were critical reviews of the literature; (4) were not dissertation papers, editorials, letter, book, and book chapter. The inclusion and exclusion criteria were assigned in the narrative reviews process for attaining a precise and meticulous articles and documents for the study. The inclusion measures include the title and abstract of the term "Islamic" and "Quality Management System" keyword search. This opens a wider range of Islamic and quality perspectives obtained. This measure was taken before further considers the exclusion measures (Ferrari, 2015; Siddaway, Wood, \& Hedges, 2019).

\section{Managing Results}

After the inclusion and exclusion in the studies drawn accordingly, which can be tailored from the introduction and methodology. The selection criteria must be set out accordingly in addressing the pre-determined objectives to avoid biases of data selection. The exclusions criteria refer to the rejected selection measures set in the searching process to address the research objectives in the study. Usually, the inclusion is based on the readings of the abstracts whilst the exclusion is based on the limitation of information provided in the full articles. It is essential to undertake the exclusion criteria is based on the readings of the abstracts and then clarification through the full texts before the exclusion criteria is fulfilled. The selection criteria of the articles in narrative reviews are illustrated in Figure 1. The inclusion and exclusion criteria establish the direction in aligning the research aims for this paper. 


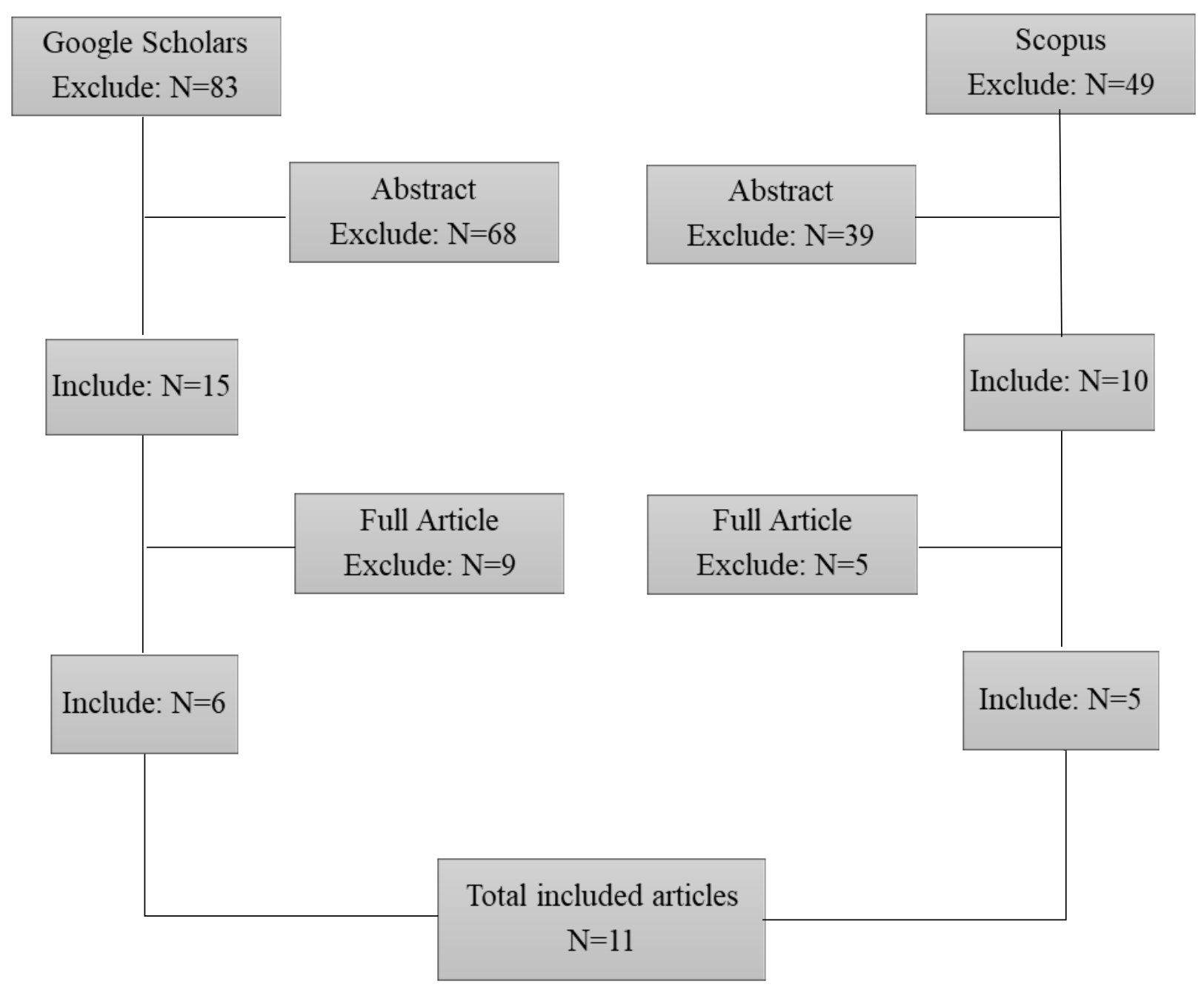

Figure 1. The Process of Searching and Its Findings

\section{Results}

Based on Figure 1, the included articles will then be analyzed to produce the detail result for this study. The identified concept from the chosen articles is presented in the Table 1 . The type of Islamic Quality Management related concepts has also been mentioned in Table 1. 
Table 1. The list of Past Researcher and the concepts mentioned.

Past Researcher

Arni, Hayaati, Ilhaamie, Albanna and Nizam (2019)

Waldan (2020)

Al-Banna, Ab.Mumin and Basir (2015)

Ahmadun, Basir and Rasip (2018)

Ahmad (2015)

Darifah (2015)

Noufal and Thacharupadikkal (2012)

Sirat, Hilmiyah and Shafiai (2016)

Idris, Zakaria, Long and Salleh, (2019)

Ishak and Osman (2019)

Mohamed, Ab.Ghani and Basir (2016)
The Islamic Quality Management related concepts

Amanah, Responsibility, Dedication, Moderation, Sincerity, Perseverance, Cleanliness, Discipline, Teamwork, Virtuous, Excellence, Niat, Ihsan, Itqan, Istiqamah, Syura, Remembrance of God, Continuous Self-Improvement

Amal Saleh, Amanah, Sincerity, Ihsan, Itqan, Muhasabah, Muraqabah, Hablum Minallah, Hablum Minal Alam, Hablum Minannas

Amanah, Sincerity, Syura, Al-Falah, Justice, Tawhid, Amar Maaruf and Nahi Munkar

Syura, Justice, Teamwork, Leadership, Customerfocus, Reward, Training and Development

Halal and Haram, Faith, Desire

Amal Saleh, Justice, Sincerity, Ihsan, Itqan, Discipline Syura, Justice, Tawhid, Unity of Purpose, Independence, Responsibility, Accountability, Selfregulation, Goodwill, Dignity, Respect, Privacy, Trust, Cross-Cultural Dialogue, Cost Efficiency, Time Efficiency, Caring, Sharing, Sincerity, Ihsan, Loyalty, Eager to Learn

Justice, Tawhid, Maqasid Al-Shariah, Maslahah, AlFalah

Amanah, Time management, Cooperation, Insaniyyah, Niat, Ihsan, Itqan, Istiqamah, Syura, Mardhatillah, Self-Improvement, Innovative, Perseverance, Tawhid

Time management, Responsibility, Ihsan, Integrity, Teamwork, Discipline

Value-based Operation, Halal and Haram, Maqasid Al-Shariah

Based on Table 1, this study found out 66 concepts which are related to Islamic Quality Management. This study found out that among those 66 concepts, the highest number of concepts mentioned in the included articles is the concepts of Ihsan which has been mentioned in 6 included articles. Followed by the concepts of Syura, Sincerity and Justice which has been mentioned in 5 included articles. Furthermore, the concepts of Amanah, Itqan and Tawhid has been mentioned in 4 included articles while the concept of Discipline, Responsibility and Teamwork. Seven concepts which are Al-Falah, Halal and Haram, Istiqamah, Amal Saleh, Niat, Perseverence and Time Management share the same number of mentioned which is 2 . Other concepts share the same amount of mentioned which is 1 . 
The summarize result of this study is portrayed in the word cloud which was initiated using Atlas.ti software. The word cloud is used this study because a word cloud can be used to summarize document content (Ennis, 2010). The word cloud is as Figure 2.

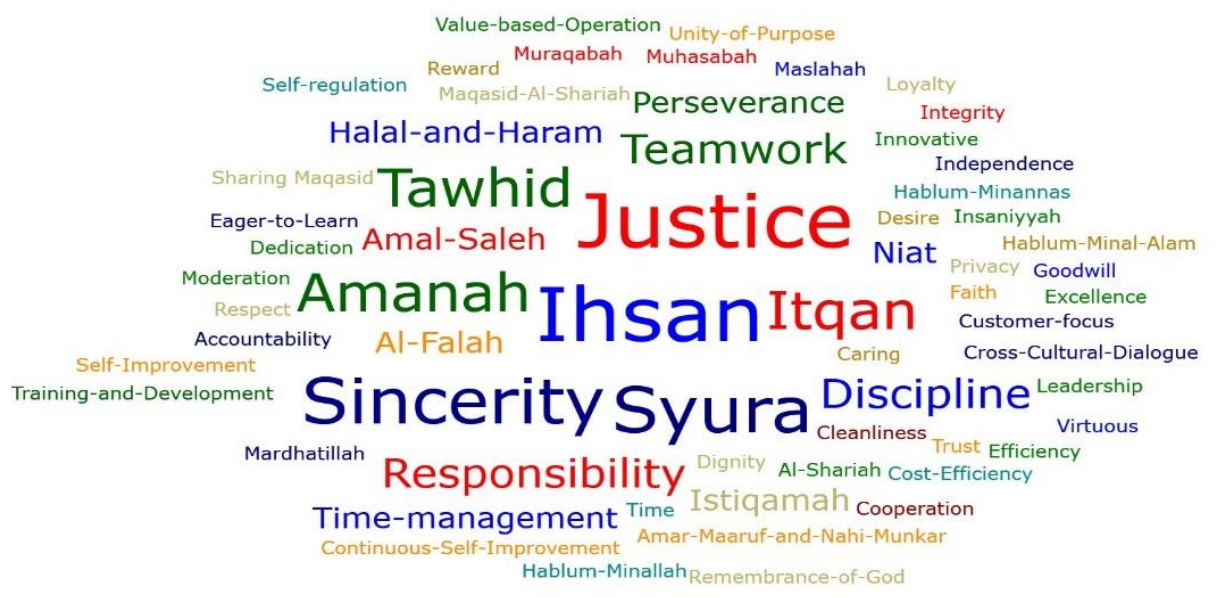

Figure 2. The Concepts which are related to Islamic Quality Management

\section{Discussion}

In this subsection, this study will be focusses on the second objectives of this paper which is to identify the classification made by past researchers which classified the concepts into principles and elements. As mentioned before, principles and elements were the core aspect for the Islamic Quality Management System. Therefore, this research will identify which of those concepts which are related to Islamic Quality Management System has been classified by the past researchers into element and principles.

Eventhough there were 66 concepts found in this study, which was related to Islamic Quality Management, however only several concepts that has been classified by past researchers into element and principles. There were 5 concepts which are classified into principles which are Syura, Itqan, Insaniyyah, Tawhid and Istiqamah. Moreover, there were 18 concepts which has been classified into elements which are Hablum MinnAllah, Hablum Minal Alam, Hablum Minannas, Syura, Teamwork, Leadership, Customer-focus, Reward, Training and Development, Faith, Desire, Justice, Dignity, Amanah, Time management, Cooperation, Niat. The findings of this study are portrayed in Figure 3 and Figure 4. 


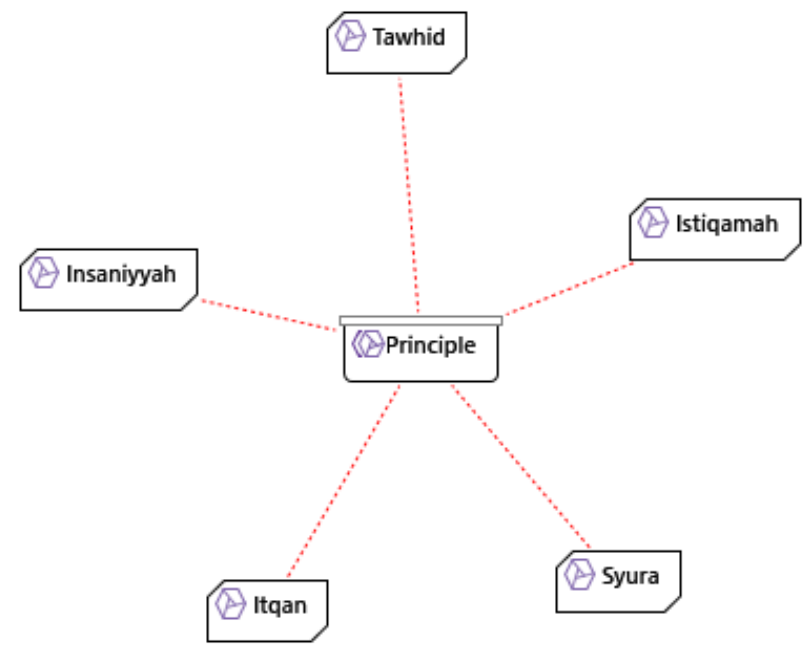

Figure 2. The principles related to Islamic Quality Management

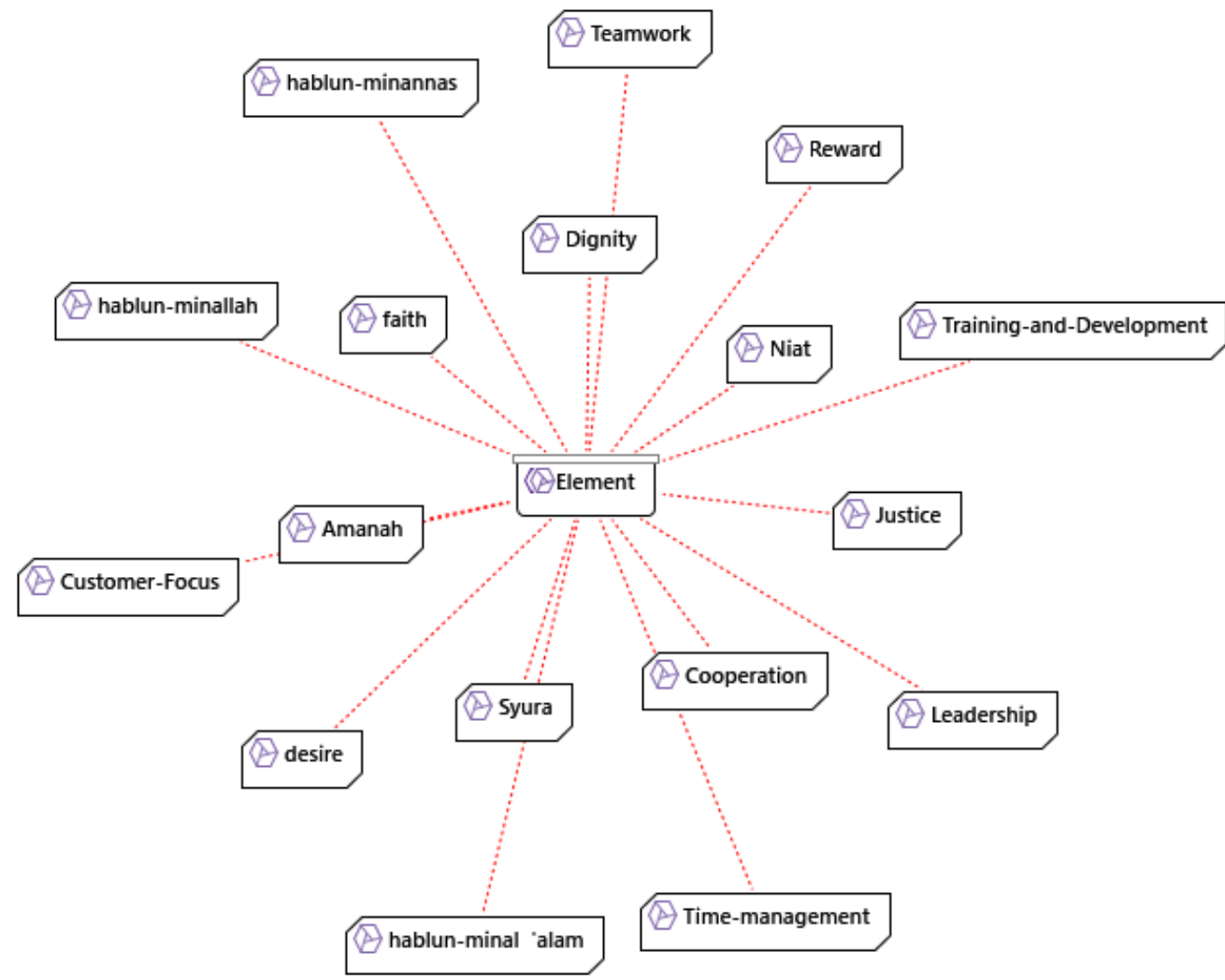

Figure 4. The Element related to Islamic Quality Management

Based on these findings, Syura has been one of the concepts which has been classified into both categories which are elements and principles. Syura has been a vital concept in not only Islamic Quality Management but also in Islamic managements. This can be proven when Islamic management scholar which is Al-Buraey (2005) discuss detailed analysis on syura. Another point to consider, another scholar on Islamic Management, Hassan (1992) created a Islamic management model known as Management by Syura. In this study, Syura has also been mentioned in 5 different articles which 2 of the articles classified Syura as principle (Ahmadun et al., 2018; Idris et al., 2019). However, when discussing on the soft factor of the implementation of Islamic Quality Management, Ahmadun et al (2018) suggested Syura as 
element instead of principles as mentioned earlier. Above all, this shown that Syura was one of the important concepts which are related to Islamic Quality Management System.

Other than Syura, the concept of Tawhid has also been categorizes in both elements principles. However, Tawhid was classified indirectly compared to Syura. According to Ahmad (2016), every institutional management must be rooted from the principle of tawhid. This study found that the classification by Idris et al (2019) similar with Ahmad (2016) which mentioned that Tawhid was a principle. Tawhid was actually mentioned indirectly by Waldan (2020) when categorized Hablum MinnAllah, Hablum Minal Alam, Hablum Minannas as element. According to Ahmad (2016), Hablum MinnAllah, and Hablum Minannas was the dimension that must be considered in any management that are based on the concept of Tawhid. Therefore, this shown that the discussions on the concepts of Tawhid must occur in any type of management that are based on Islam. Another point to consider, the concept of tawhid was also within the Management by Shura model management by Hassan (1992) and also discussed by Mokhtar and Isa (2015) on the implementation of Tawhid towards management. This shown that Tawhid was one of the basic principles in Islamic Management and will be the basic principle in Islamic Quality Management.

Another point to consider, in building the Management by Syura, Hassan (1992) pointed out three different concepts which has become the fundamental of the model. The three concepts are Ihsan, Faith and Amal Saleh. Based on the findings from this study, Ihsan was the most discussed concepts in all included articles while faith and amal saleh also been mentioned by the past researchers. However, unlike Syura, Ihsan has not been classified as elements or principles by the past researchers. Between faith and amal saleh, only faith has been classified into element by Ahmad (2015) while amal saleh was not been classified as such Ihsan. Since there was Islamic management scholar's argument on the importance of these three concepts and this study also found out similar pattern which all these three are considered important.

Itqan has also been considered as a very important concepts in Islamic Quality Management. This has been proven when Musa and Salleh (2005) discusses this concept as an element in Ideal Total Quality Management from Islamic perspective. However, this study found out that Darifah (2015) mentioned that itqan was considered principles in Islamic Quality Management not element as mentioned by Musa and Salleh (2005). Hammoudeh (2012) was another researcher that mentioned on itqan. However, Hammoudeh (2012) argued that itqan can be considered both as elements or as principles. The number of discussion and the categorization of the concept found in this study shown that shown that itqan was equally important as other concepts.

These were among the concept which this study found that are important to form an Islamic Quality Management System due to the high number mentioned by past researcher and has been mentioned by Islamic management scholars. However, this does not conclude that the other concepts found within this study are not important. Further research and analysis must be done on all these concepts so that the Islamic concept of Quality Management can be establish. To achieve this, the classification of all these concepts is equally important for further studies so that these concepts can be used to form a model or a framework for Islamic Quality Management System. 


\section{Conclusion}

This review found that studies on the Islamic Quality Management System has already come out with many concepts that can be used to establish a holistic quality management system that are based on Islamic philosophy. This research also found out that several of this concept has already been categorized into elements and principles. However, this review found out that the concepts that become the most discussed concepts which is ihsan has not been categorized yet into elements and principles. Conversely, other that ihsan, this research also acknowledges several concepts that are consider important due to high number of discussion and has been mentioned by Islamic management scholars such as itqan, tawhid and amal saleh. As for future research, this study found the urgency to analyze further on all the concepts found in this study and categorized into elements and principles. This can assist future research into establishing Islamic Quality Management System model or framework that are holistic and suitable to be implemented towards Muslims and Islamic institutions.

\section{Corresponding Author}

Fadzila Azni Ahmad

Centre for Islamic Development Management Studies (ISDEV), Universiti Sains Malaysia, 11800 USM, Penang

Email: sukainah@usm.my

\section{References}

Ahmad, F. A. (2015). Towards A Redefinition Of Quality Management In Accordance With Islam 1 This paper aims to discuss the need to redefine quality management in accordance with Islam by analysing the The management of Islamic development institutions of today are more likel. International Journal for Innovation Education and Research, 3(11), 137-148.

Ahmadun, M., Basir, S. A., \& Rasip, O. M. (2018). Soft Factor In the Implementation of Quality Management Program in Majlis Agama Islam Selangor (MAIS). Sains Humanika, 3(2004), 9-20.

Azrin, A. A., Amirul, A., \& Hakim, A. (2015). Model Pengurusan Islam Berasaskan Ayat Pertama Surah Al-Fatihah. Proceedings of IDMAC2015, 319-331.

Basir, S. A., Azmi, I., Ismail, S. H., Ibrahim, P., \& Mohamed, H. A. (2017). Malaysian Islamic quality management system MS1900: An implementation steps at Malacca Zakat Center. Humanomics, 33(2), 239-254. https://doi.org/10.1108/H-10-2016-0078

Darifah, U. H. (2015). Konsep Total Quality Management Edward Sallis dalam Perspektif Pendidikan Islam. Online Thesis, 10(1), 151-206. Retrieved from https://tesis.risetiaid.net/index.php/tesis/article/view/14/8

Ennis, A. (2010). Indicators of Content : the role of word clouds in the creation of summaries (Loughborough University). https://doi.org/10.1017/CBO9781107415324.004

Ahmad, F. A. (2016). Konsep Pengurusan Institusi Pembangunan Berteraskan Islam (Second). Kuala Lumpur: Dewan Bahasa dan Pustaka.

Ahmad, F. A. (2019). Pendefinisian Pengurusan Kualiti Menurut Perspektif Islam dan Konvensional. In Pengurusan Kualiti Institusi Pembangunan Islam di Brunei Darussalam dan Malaysia (Pertama, pp. 1-28). Gadong: UNISSA Press.

Hammoudeh, M. M. (2012). Islamic Values and Management Practices: Quality and Transformation in the Arab World (R. Lessem \& A. Scieffer, Eds.). Surrey: Gower Publishing Limited. 
Al-Banna, H., M., Ab. Mumin, A. G., \& Arni, B. (2015). Faktor-faktor kejayaan dalam Pelaksanaan MS1900:2005: Satu kajian Kualitatif di Institusi Pengajian Tinggi Swasta, Malaysia. Sains Humanika, 4(1), 29-36.

Al-Banna, H., Ab Mumin Ab Ghani, \& Siti Arni Basir. (2015). The values of Islamic quality management system based on the Quran and integration of scientific knowledge. Jurnal Syariah, 23(1), 25-52.

Hasliza, M. A., Arni, B., \& Musaiyadah, A. (2016). Implementation of the Islamic Quality Management System MS1900 and its Benefits: A Case Study at the Department of Hajj, Waqf and Zakah, Malaysia. Global Journal Al Thaqafah, 6(2), 85-98. https://doi.org/10.7187/gjat11620160602

Idris, M., Zakaria, W. F. A., Long, A. S., \& Salleh, N. (2019). Kualiti Kerja dalam Organisasi: Tinjauan dari Perspektif Pengurusan Islam. International Journal of Islamic Thought, 15(1), 60-70. https://doi.org/10.24035/ijit.15.2019.006

Ishak, A. H., \& Osman, M. R. (2019). Understanding Islamic perspectives on quality management: From concept to practice. Journal of Engineering and Applied Sciences, 14(4), 1262-1266. https://doi.org/10.3923/jeasci.2019.1262.1266

Kamaluddin, N., Hassan, Z., Wahab, R. A., \& Hussein, R. M. (2014). Principles of Management (Second Edi). Kuala Lumpur: Oxford University Press.

Othman, K. (2017). Quality Management System vs. Maqasid Shariah Islamic Quality Management System vs. Customer Satisfaction. International Journal of Academic Research in Business and Social Sciences, 7(13), 20-34.

https://doi.org/10.6007/ijarbss/v7-i13/3182

Mohamad, M. H., \& Mansor, F. (2018). A Conceptual Study on Shariah Compliance on Risk Mitigation of MS1900-Certified Companies. In Tafhim: IKIM Journal of Islam and Contemporary World 11 (pp. 113-149). IKIM Press.

Mohamed, H. A. B., Ab. Ghani, A. M., \& Basir, S. A. (2016). Factors influencing the implementation of Islamic QMS in a Malaysian public higher education institution. Total Quality Management and Business Excellence, 27(9-10), 1140-1157. https://doi.org/10.1080/14783363.2015.1064765

Hassan, M. A. (1992). The Tawhidic Approach in Management and Public Administration (First). Kuala Lumpur: National Institute of Public Adminstration (INTAN).

Mokhtar, A., \& Isa, N. M. (2015). Pengurusan dalam Islam (Pertama). Shah Alam: Oxford Fajar Sdn Bhd.

Al Buraey, M. (2005). Management Principles Derived from the Sources of Islam. In M. Musa \& S. M. S. S. M. Salleh (Eds.), Quality Standard from Islamic Perspectives (First, pp. 2742). Kuala Lumpur: Institut Kefahaman Islam Malaysia (IKIM).

Musa, M., \& Salleh, S. M. S. S. M. (2005). The Elements of an Ideal Total Quality from the Islamic Perspectives. In M. Musa \& S. M. S. S. M. Salleh (Eds.), Quality Standard from Islamic Perspectives (First, pp. 149-174). Kuala Lumpur98: Institut Kefahaman Islam Malaysia (IKIM).

Noufal, P. K., \& Thacharupadikkal, S. M. (2012). Sustainable model of organizational management in the perspectives of Islam: A study based on Jamaat-E-Islami Hind. Purushartha, 5(1), 110-124.

Olejniczak, T. (2013). Japanese Management : 50 Years of Evolution of the Concept. 4(26), 726.

Sarion, A., Bustamam, U. S. A., \& Shaharudin, A. (2014). Towards MS1900 : 2014 quality management system from Islamic perspective: A case study at MACS. International 
Journal of Islamic and Civilizational Studies, 1(1), 8-17.

Sirat, A. H., Hilmiyah, N., \& Shafiai, M. H. M. (2016). Al Maslahah based quality management: A theoretical overview. American Journal of Applied Sciences, 13(3), 243-250. https://doi.org/10.3844/ajassp.2016.243.250

Arni, B., Hayaati, S. I., Ilhaamie, A. G. A., Albanna, M., \& Nizam, K. (2019). Nilai-Nilai Islam Dalam Pelaksanaan Sistem Pengurusan Kualiti ISO 9000: Kajian Kes Di Institusi Pengajian Tinggi Malaysia. International Journal of Islamic and Civilizational Studies, 6(2), 79-92.

Waldan, R. (2020). Total Quality Management dalam Perspektif Islam. Journal of International Conference On Religion, Humanity and Development, 1(1), 259-268. 